\title{
Biological Control of Powdery Mildew on Zinnia (Zinnia elegans, L) Using Some Biocontrol Agents and Plant Extracts
}

\author{
Mahmoud Abdelnabi Hegazi (Corresponding author) \\ Department of horticulture, Faculty of Agriculture, Kafr El-Sheikh University \\ Kafr El-Sheikh, Egypt \\ Tel: 201-6282-1639Ｅ-mail: abohegazi@yahoo.com \\ Gabr Abdelwanes El-Kot \\ Department of Agriculture Botany (Phytopathology branch), Faculty of Agriculture \\ Kafr El-Sheikh University, Kafr El-Sheikh, Egypt \\ Tel: 201-0617-9370Ｅ-mail: g_elkot200@yahoo.com
}

\begin{abstract}
Powdery mildew is a potentially serious disease of Zinnia (Zinnia elegans). The disease is caused by the air-borne fungus Erysiphe cichoracearum and it is an occasional disease of Zinnia in Egypt. Culture filtrates of Trichoderma harzianum, Epicoccum sp., Streptomyces endus and an actenomycetal isolate in addition to two plant extracts i.e. miswak (Salvadora persica) and henna (Lawsonia inermis) were evaluated to control powdery mildew disease of Zinnia plants. Culture filtrates of the aforementioned biocontrol agents were used as 25 and $50 \%$. Bioassays were conducted under field conditions during the two successive seasons of 2006 and 2007 at the Experimental Farm of the Fac. of Agric., Kafr El-Sheikh Univ., Egypt to test the efficacy of these culture filtrates applied to protect Zinnia plants from powdery mildew disease.

Spraying zinnia plants four times, beginning from June $15^{\text {th }}$ with one week interval by a hand atomizer under field conditions with the previously culture filtrates and the two plant extracts gave sufficient control to powdery mildew disease. The obtained results showed that, all used treatments led to significant decrease in both disease incidence and severity compared with control treatment. The highest disease incidence inhibition was obtained when Epicoccum sp. and T. harzianum were used as $50 \%$ (v/v) sterilized water followed by henna and miswak extracts were used, respectively. Sprayed plants recorded best results for most growth characters, peroxidase (POX) and polyphenol oxidase (PPO) enzymes activity compared unsprayed one. In conclusion, biocontrol agents and some plant extracts can be substitutes to fungicides as an alternative and safe method for controlling powdery mildew disease of Zinnia.
\end{abstract}

Keywords: Zinnia elegans, Powdery mildew, Biological control, Biocontrol agents

\section{Introduction}

Zinnia (Zinnia elegans) is an herbaceous summer annual flower blooming from mid-summer all the way until frost and belongs to Family Asteraceae. Zinnias are true American natives that originated from the Southwest US, Mexico and Central America. Hybridizers have turned it into one of the most popular cut flower or bedding plants. However, Zinnia plants are attacked with various diseases causing losses in cut flowers yield, Powdery mildew caused by Erysiphe cichoracearum is one of the most serious diseases of Zinnia in Egypt.

Application of chemical fungicides to protect plants from the attack of the pathogenic fungi was the primary means for controlling diseases. In recent years chemical fungicides have become less effective due to the development of pathogen resistance beside the potentially undesirable effects of the fungicides on human, plants and other beneficial organisms (Thomas, 1986 and Manandhar et al., 1988). Biological control methods could be considered as an alternative of chemical control. Successful biological control of foliar diseases has been achieved by a number of researchers under greenhouses and field trials using fungal and bacterial antagonists (Singh et al., 2000; Abd El-Moneim, 2001; Mosa, 2002; El-Gamal, 2003; Kamel, 2003,;Saber et al., 2003; Mc Grath, 2004 and Hussein et al., 2007). Plant extracts were recently used to control many pathogens and diseases (El-Shoraky, 1998 and El-Kazzaz et al., 2003). Plant extracts and biocontrol agents induced host resistance through increased activity of many enzymes such as peroxidase and poly phenol oxidase which playing a 
defense role against invading pathogens (Kohl and Fokkema, 1998; Caruso et al., 2001 and Nawar and Kuti, 2003).

The current investigation was planned to study the ability of cell free culture filtrates of Trichoderma harzianum, Epicoccum sp., Streptomyces endus and an actenomycetal isolate in addition to two plant extracts, extracted from miswak (Salvadora persica) and henna (Lawsonia inermis) to control powdery mildew disease of Zinnia plants under field conditions.

\section{Material and Methods}

Seeds were sown in nursery beds on March $15^{\text {th }}$ in both seasons and seedlings were transplanted in May $1^{\text {st }}$ to a clay soil in plots $1 \times 1.5 \mathrm{~m}^{2}$ at $50 \mathrm{~cm}$ apart as twins in the hill, and each bed was divided into two parts $(1 \mathrm{x} 0.75$ $\mathrm{m}^{2}$ ), so each part contained 12 plants (6 hills) and considered a replicate. Therefore, every treatment consisted of 36 plants (18 hills) in the three replicates. The experiment was arranged in a completely randomized block design. Plants including control were fertilized with $\mathrm{N}, \mathrm{P}$ and $\mathrm{K}$ at rates of 100,200 and $100 \mathrm{~kg} / \mathrm{fed}$., respectively beginning from May $15^{\text {th }}$ and repeated three times with two weeks interval. The used fertilizers were ammonium sulphate " $20 \% \mathrm{~N}$ ", calcium super phosphate " $15.5 \% \mathrm{P}_{2} \mathrm{O}_{5}$ " and potassium sulphate " $48 \% \mathrm{~K}_{2} \mathrm{O}$ ". The common agricultural practices i.e. watering, weeding control, etc. were done whenever plants needed.

\subsection{Culture filtrates}

Culture filtrates of Trichoderma harzianum, Epicoccum sp., Streptomyces endus and an actenomycetal isolate were obtained by growing these isolates on PD broth for 15 days at $26-28{ }^{\circ} \mathrm{C}$, and then centrifuged at $5,000 \mathrm{rpm}$ for $15 \mathrm{~min}$., then the supernatant was filtered by filter glass (El- Boghdady, 1993). After that filtrates were diluted at 25 and $50 \%(\mathrm{v} / \mathrm{v})$ by a sterilized water. These aforementioned isolates were previously isolated and identified by El-Kot (2007).

\subsection{Preparation aqueous extract of henna and miswak}

Leaf samples (100 gm) of henna (lawsonia inermis) powdered was macerated with $100 \mathrm{ml}$ distilled water for 24 $\mathrm{h}$ at $4^{\circ} \mathrm{C}$. The macerate was centrifuged at $4000 \mathrm{rpm}$ for $30 \mathrm{~min}$, then filtered through filter paper and served as the mother extract. The mother extract was diluted to $25 \%$ with distilled water and sprayed on the plant (Satish et al., 2007).

Twenty grams of miswak (Salvadora persica) stem powdered were soaked in $100 \mathrm{ml}$ of distilled water for $24 \mathrm{~h}$ at $4{ }^{\circ} \mathrm{C}$. The mixtures were centrifuged at $2000 \mathrm{rpm}$ for $10 \mathrm{~min}$., and the extract was filtered through filter paper and sprayed on the plant (Al Bagieh et al. 1994).

\subsection{Control of powdery mildew under field conditions}

Under field conditions culture filtrates of Trichoderma harzianum, Epicoccum sp., Streptomyces endus and an actenomycetal isolate ( 25 and $50 \% \mathrm{v} / \mathrm{v}$ sterilized water) in addition to two plant extracts of Salvadora persica and Lawsona inerms were used to control powdery mildew disease of Zinnia plants.

The prepared microbial culture filtrates and plant extracts were introduced to the experimented plants. Culture filtrates and plant extracts were amended with calculated aliquots of an adhesive surfactant (New-Film 1265 registered by Ministry of Agric. and Reclamation Lands, Egypt) as recommended (30 ml/1001) and hand homogenized before fine spraying on the experimental plants (Abd El-Moneim, 2001). Plants were sprayed with each of aforementioned treatments as soon as the first signs of the symptoms were observed. For control treatments, plants were sprayed with water and in the other treatments, Kimazien $75 \%$ as a fungicide was also used. Percentage of disease incidence and severity were determined after 7 days from the last spray according to the scale reported by Horsfall and Barrett (1945) and Biswas et al., (1992).

\subsection{Enzymes extraction and assay}

Leaves samples from each zinnia plants treatment, healthy and infected were collected $24 \mathrm{~h}$ after sprayed with culture filtrates of T. harzianum, Epicoccum sp, Str. Endus, one isolate of actenomycetes, plant extracts of $S$. persica and L. inerms for peroxidase and polyphenol oxidase enzymes activity assay. In addition, untreated healthy and infected leaves were used as control. Enzyme extract was obtained by grinding leaf tissue in $0.1 \mathrm{M}$ sodium phosphate buffer at $\mathrm{pH} 7.1(2 \mathrm{~m} / \mathrm{g}$ leaf tissues) in a porcelain mortar. The extracted tissues were strained through four layers of cheesecloth. Filtrates were centrifuged at $3000 \mathrm{rpm}$ for $20 \mathrm{~min}$. at $6^{\circ} \mathrm{C}$. The clear supernatants were collected and considered as crude enzyme extract. Peroxidase (POX) activity was determined according to the method of Allam and Hollis (1972) by measuring the oxidation of pyrogallol to pyrogalline in the presence of hydrogen peroxide. Peroxidase activity was measured following the changes in absorbance at $425 \mathrm{~nm}$ every $1 \mathrm{~min}$. up to 4 minutes. Polyphenol oxidase (PPO) was determined according to Maxwell and 
Batman (1976). The changes in absorbance was following spectrophotometrically measured at $495 \mathrm{~nm}$, and recorded every $1 \mathrm{~min}$. up to $4 \mathrm{~min}$. All measurements were assayed using Beckman Spectrophotometer Duß7400.

At the end of the experiment, the following data were recorded (average of both seasons):

1. Growth parameters as plant height $(\mathrm{cm})$, branch number/ plant, leaf area $(\mathrm{cm} 2)$, shoots fresh and dry weights /plant $(\mathrm{g})$, root length $(\mathrm{cm})$ and roots fresh and dry weights /plant $(\mathrm{g})$, flower number /plant, flower diameter $(\mathrm{cm})$ and flower fresh and dry weights $(\mathrm{g})$.

2. Total green colour (SAPD) was measured using a portable chlorophyll meter (Minolta SPAD- 502, Japan).

Means between treatments were compared with Duncan's Multiple Range Test according to Snedecor and Cochran (1982).

\section{Results}

\subsection{Effect on disease incidence and severity}

Data presented in Table (1) showed that all used treatments were significantly decreased disease incidence (average number of powdery mildew spots/leaf) and disease severity (percent of surface infected area) on Zinnia plants. Results indicated that, the best control of the studied disease was obtained when culture filtrates were sprayed on Zinnia plants as $50 \%$ (v/v) sterilized water. Meantime, culture filtrates of Epicoccum $\mathrm{sp}$. as $50 \%$ was the most efficient treatment on disease incidence and severity in the two successive seasons. It significantly decreased disease and severity from 30.78-2.03\%, 87.2-6.4\%, respectively in 2006 season and from 35.69-2.04\%, 91.5-6.8\%, respectively in 2007 season followed by cell free culture filtrates of Trichoderma harzianum, since it decreased disease incidence and severity from 30.78-2.08\%, 87.2-7.7\%, respectively in 2006 season and from $35.69-3.00 \%, 91.5-8.1 \%$ respectively in 2007 season. However, culture filtrates of Streptomyces endus was the least effective treatment used as either $25 \%$ or $50 \%$. In general, all used treatments gave better or similar results with those obtained when the fungicide Kimazien $75 \%$ used.

\subsection{Effect on peroxidase and polyphenol oxidase activity}

The effect of spraying zinnia plants with culture filtrates of T. harzianum, Epicoccum sp., Str. Endus, one isolate of actenomycetes, $S$. persica and L. inerms extracts on peroxidase and poly phenol oxidase enzymes activity was determined after $24 \mathrm{~h}$ from last spraying. In this study, results showed that peroxidase and polyphenol oxidase activities were significantly increased as a result of spraying Zinnia plants with these treatments (Tables, 2 and 3).

The highest activity of peroxidase was observed when culture filtrates (50\%) of Epicoccum sp. was sprayed on zinnia plants $(1.747,1.756,1.768,1.777)$ followed by plant extract of $L$. inerms $(1.734,1.741,1.746,1.758)$ compared with control $(0.403,0.405,0.409,0.413)$. Similarly, culture filtrates $(50 \%)$ of Epicoccum sp. caused the highest activity of polyphenol oxidase than other treatments as gave $0.186,0.220,0.224$ and 0.227 followed by $T$. harzianum at $50 \%$ as gave $0.115,0.130,0.0134$ and 0.140 against $0.043,0.071,0.073$ and 0.077 for control (Table, 3). Meantime, results indicated that, the high concentration of used culture filtrates caused higher activity of both peroxidase and polyphenol oxidase than the lowest one. For example peroxidase activity caused by spraying Zinnia plants with 50\% culture filtrates of T. harzianum was 1.007, 1.020, 1.037, 1.059 compared with $0.501,0.506,0.511,0.517$ which was caused by spraying with $25 \%$.

\subsection{Effect on some growth and flowers aspects}

\subsubsection{Plant height, branches number and leaf area}

The significantly tallest plants resulted from the treatment of Epicoccum sp. at both 50 and $25 \%$ as recorded 155.19 and $149.74 \mathrm{~cm}$, respectively (Fig. 1) followed by Streptomyces endus at 50\% and Kemah zein $75 \%$ as gave 143.12 and $139.70 \mathrm{~cm}$, respectively. The shortest plants were that treated with Trichoderma harzianum at both percentages 25 and 50\% and distilled water (control) as gave 116.18, 118.62 and $90.88 \mathrm{~cm}$, respectively.

The highest number of branches resulted from the plants treated with Epicoccum sp. at 50\% and Kemah zein $75 \%$ as recorded 9.69 and 8.06, respectively. The least branch number resulted from the plants treated with Lawsonia inerms and Salvadora persica extracts as recoded 5.58 and 5.54, respectively against 3.86 for control (distilled water). As for leaf area, it is obvious that the corresponding treatment at both 50 and $25 \%$ gave the widest leaves compared to the other treatments as recorded 39.55 and $37.13 \mathrm{~cm}^{2}$ followed by the treatments of isolate of actinomycete at $50 \%$ and Lawsonia inermis extract as recorded 36.68 and $36.39 \mathrm{~cm}^{2}$, respectively. The narrowest leaves resulted from plants treated with Salvadora persica extract and distilled water (control) as recorded 31.29 and $24.41 \mathrm{~cm}^{2}$, respectively. 


\subsubsection{Fresh and dry weights of shoots and root length}

It is evident from Fig.2 that plants treated with Epicoccum sp. at both 50 and $25 \%$ followed by isolate of actinomycete at $50 \%$ and Kemah zein $75 \%$ gave the heaviest fresh shoots as recorded 308.59, 303.36. 301.64 and $301.62 \mathrm{~g} /$ plant, respectively. Whereas, the heaviest shoots dry weight resulted from plants treated with isolate of actinomycete at both 50 and $25 \%$, Streptomyces endus at $50 \%$ as gave $40.09,39.18$ and $39.35 \mathrm{~g} / \mathrm{plant}$, respectively. The lightest fresh and dry shoots resulted from plants treated with Salvadora persica extract and distilled water (control) as recorded 177.60 and $105.89 \mathrm{~g}$ fresh weight/plant and 19.68 and $10.24 \mathrm{~g}$ dry weight/ plant. The other treatments gave a gradually intermediate values without significant differences among them in most cases.

As for root length, it is clear that plants treated with Epicoccum sp. at both 50 and $25 \%$ followed by isolate of actinomycete at $50 \%$ gave the tallest roots as recorded $16.21,14.78$ and $14.39 \mathrm{~cm}$, respectively against $8.60 \mathrm{~cm}$ for control (distilled water).

\subsubsection{Fresh and dry weights of roots}

All treated plants gave a significantly heavier fresh and dry roots than control (distilled water) (Fig. 3). The treatment of Epicoccum sp. at 50\% gave the highest values for both roots fresh and dry weights as recorded 13.74 and $1.94 \mathrm{~g} /$ plant, respectively. This was followed by plants treated with isolate of actinomycete at $50 \%$ and Kemah zein $75 \%$ for roots fresh weight as recorded 13.18 and $13.16 \mathrm{~g} /$ plant, and that treated with Streptomyces endus at $50 \%$ and Kemah zein $75 \%$ for roots dry weight which recorded 1.85 and $1.84 \mathrm{~g} /$ plant, respectively. The lowest values obtained from plants treated with Salvadora persica extract and distilled water (control) for roots fresh weight and Lawsonia inermis extract and distilled water (control) for roots dry weight as recorded 12.07, $9.98,1.69$ and $1.37 \mathrm{~g} /$ plant, respectively

\subsubsection{Flower number}

It is clear from Fig. 3 that the highest number of flowers obtained when plants treated with Epicoccum sp. at both 50 and $25 \%$ followed by Kemah zein $75 \%$ and isolate of actinomycete at 50\% as gave 23.40, 21.87 and 21.57, respectively. The least flower number observed on plants treated with Lawsonia inermis extract or distilled water (control) which recorded 14.87 and 12.13 , respectively.

\subsubsection{Flower diameter and flower fresh and dry weights}

The biggest flowers were observed on either plants treated with isolate of actinomycete or Epicoccum sp. at both 50 and $25 \%$ without significant differences among them as gave 6.94, 6.68, 6.76 and $6.77 \mathrm{~cm}$, respectively (Fig, 4). The smallest flowers $(4.73$ and $3.65 \mathrm{~cm})$ resulted from plants treated with Salvadora persica extract and control (distilled water).

As for flower fresh and dry weights Fig. 4 refer that the heaviest flower fresh and dry weights resulted from plants treated with either Epicoccum sp. or isolate of actinomycete at $50 \%$ as recorded 4.87 and $4.59 \mathrm{~g}$ fresh weight and 0.97 and $0.98 \mathrm{~g}$ dry weight, respectively. The lightest flower fresh weight $(2.92$ and $2.06 \mathrm{~g}$ ) resulted from plants treated with Salvadora persica extract and control (distilled water) whereas, plants treated with Trichoderma harzianum at $25 \%$ and distilled water (control) gave the lightest flower fresh weight $(0.51$ and $0.42 \mathrm{~g})$.

\subsection{Effect on total green colour}

The greenest plants were that treated with either Epicoccum sp. and Streptomyces endus each at 50\% or Kemah zein $75 \%$ without significant differences as recorded $34.61,34.53$ and 34.24 SAPD, respectively. The pale leaves were noticed on plants treated with Trichoderma harzianum at $25 \%$ and distilled water (control) as recorded 29.67 and 26.39SAPD, respectively.

\section{Discussion}

The present work was designed to reduce using chemicals in agriculture process and find out the most suitable non-chemical method to protect Zinnia plants against powdery mildew disease. In this study, data obtained showed that all used culture filtrates significantly reduced disease incidence and severity of zinnia powdery mildew accompanied with improving the most studied growth characters and total green colour. These results might be due to that Epicoccum sp. and Trichoderma harzianum inhibit disease by producing some antifungal substances, i.e. gliotoxin and some growth regulators. These compounds are amphilic, membrane active surfactants and when sprayed on plant surface, prior infection led to stimulate plant resistant and enforce treated plants to produce some metabolites which depress the pathogen and some growth promoters such as indols which increased plant growth generally (Abd El-Moity, 1981; Abd El-Moity, 1985; Sanker and Jeyarajan 1996; 
Reguchander et al., 1997; Elad et al., 1998; Umseha et al., 1999; Bolar et al., 2000; Howell et al., 2000; El-Gamal, 2003; Saber et al., 2003; El-Kot, 2007 and Hussein et al., 2007).

The reduction in disease incidence and severity of Zinnia powdery mildew with spraying Salvadora persica and Lawsona inermis extracts might be due to the antimicrobial activities towards the studied pathogen. These results are consistent with previous investigations (Farag et al., 1989; Mc Cutheon et al., 1994; Navarro et al., 1996; El-Kazzaz et al., 2003 and Satish et al., 2007). Culture filtrates and plant extracts gave an increment of peroxidase and polyphenol oxidase enzymes activity which indicate a positive relationship between increases in peroxidase and polyphenol oxidase enzymes activity and reduction in disease incidence and severity of Zinnia powdery mildew.

Many investigators supported this idea since they stated that there are positive relationships between peroxidase enzyme and resistance developed in plants (Deacon and Berry, 1993 and Kohl and Fokkema, 1998, Nawar and Kuti, 2003 and Emeran et al., 2006). Similarly, Caruso et al., 2001 stated that peroxidase enzyme is playing a defense role against invading pathogens of wheat kernels. Other investigators reported that peroxidase is known to be involved in the oxidation of polymerization of hydroxycinnamyl alcohols to yield lignin and cross-linking isodityrosine bridges in cell wall, peroxidase also produces free radicals and hydrogen peroxide which are toxic to many microorganisms (Vance et al., 1980; Fry, 1982 and Pena and Kuc, 1992). Also, Ride,1983 and Tarrad,1993 stated that increase in peroxidase activity enhances lignification in response to infection with pathogens which may restrict fungal penetration.

\section{References}

AbdEl-Moity, T.H. (1981). Further studies on the biological control of white rot disease of onion. Ph.D. Thesis, Fac. Agric., Minufya Univ., pp. 135.

Abd El-Moity, T.H. (1985). Effect of single and mixture of Trichoderma harizianum isolates on controlling three different soil-borne pathogens. Egypt. J. Microbiol., Special Issue, 111-120.

Abd El-Moneim, Maisa, L. (2001). Evaluation of some non-chemical methods to control some soil borne fungi and foliage diseases of cucumber. Ph.D. Thesis, Fac. Agric., Zagazig Univ., Egypt. 143 pp.

Al Bagieh, N. H., Idowu, A. and Salako N. O. (1994). Effect of aqueous extract of miswak on the in vitro growth of Candida albicans. Microbios., 80(323): 107-13

Allam, A. I. and Hollis, S. P. (1972). Sulfide inhibition of oxidase in rice root. Phytpathology, 62: 634-639.

Biswas, S., Teotia, R. S. and Manil, S.K. (1992). Some field observations on the severity of powdery mildew ( Phyllactinia corylea ) in mulberry. Indian J. Seric., 31: 67-69.

Bolar, J. P., Norelli, J. L., Wong, K. W., Hayes, C. K., Harman, Q. E. and Aldwinckle, H. S. (2000). Expression of endochitinase from Trichoderma harizianum in transgenic apple increases resistance to apple scab and reduces vigor. Phytopathology, 90: 72-77.

Caruso, C., Chilosi, G., Leonard, L., Bertin, L., Magro, P., Buonocore, V. and Caporal, C. (2001). A basic peroxidase from wheat kernel with antifungal activity. Phytochemestry, 58: 743-750.

Deacon, J.W. and Berry, L.A. (1993). Biocontrol of soil-borne plant pathogens: Concepts and their application. Pestic. Sci., 117-426.

Elad, Y., Kirshner, B., Yehuda, N.and Sztejnberg, A. (1998). Management of powdery mildew and grey mold of cucumber by Trichoderma harizianum T39 and Ampelomyces quisqualis AQ10. Biocontrol, 43(2): 241-251.

El-Boghdady, M.M.E. (1993). Integrated postharvest diseases management of certain pome fruits. Ph. D. Thesis, Fac. Agric. Al-Azhar Univ.

El-Gamal, Nadia, G. (2003). Usage of some biotic and abiotic agents for induction of resistance to cucumber powdery mildew under plastic house conditions. Egypt. J. Phytopathol, 31(1-2): 129-140.

El-Kazzaz, M.K., El-Assiuty, E. M., Badr, M.M., El-Zahaby, H. M. and Gouda, M.I. (2003). Effect of some plant extracts and essential oils on controlling sugar beet root rot disease caused by Sclerotium rolfsii Sacc. Proc. $10^{\text {th }}$ Congress of Phytopathology, Giza, Egypt, December. 237-248.

El-Kot, G. A. N. (2007). Biological control of black scurf and dry rot of potato. Proc. $10^{\text {th }}$ Congress of Phytopathology, Giza, Egypt (in press).

El-Shoraky, Fathia, S. A. (1998). Using extracts and oils of some plants in controlling plant diseases. Ph. D. Thesis, Fac. of Agric. Kafr El-Sheikh, Tanta Univ., 187 pp. 
Emeran, A.A., Belal, E. B.A. and El-Zahaby, H.M. (2006). Biological control of faba bean chocolate spot disease caused by Botrytis fabae. J. Agric. Res. Tanta Univ., 32(2): 243-258.

Farag, R.S, Daw, Z.Y., Hewedi, F.M. and El-Baroty, G.S.A. (1989). Antimicrobial activity of some spice essential oils. J. Protec., 52(9) : 665-667.

Fry, S.C. (1982). Isodityrosine a new amino acid from plant cell wall glycoprotein. Biochem. J., 204: 449-455.

Horsfall, J. C. and Barratt, A. (1945). An improved grading system for measuring plant diseases. Phytpathology, 35: 655-658.

Howell, C. R., Hanson, L. E., Stipanovic, R. D. and Puckhaber, L. S. (2000). Induction of terpenoid synthesis in cotton roots and control of Rhizoctonia solani by seed treatment with Trichoderma virens. Phytopathology, 90: 248-252.

Hussein, M. A. M, Hassan, M. H. A., Allam, A. D. A. and Abo-El-Yous, K. A. M. (2007). Management of stemphylium blight of onion by using biological agents and resistance inducers. Egypt. J. Phytopathol., 35 (1): 49-60.

Kamel, S. M. H. (2003). Antagonistic effects of some microbial inhabitants on phylloplane of squash plants towards Sphaerotheca fuliginea. Ms. C. Thesis Fac. of Agric. Kafr El-Sheikh, Tanta Univ., 94 pp.

Kohl, I. and Fokkema, N.J. (1998). Strategies of biological control of necrotrophic fungal foliar pathogens. In Plant-Microbe interactions and biological control (G. Boland and L.D. Kuykendall, Eds.). Marcel Dekker, Inc., New York W. pp.49-88.

Manandhar, J. B., Hartman, G.L. and Sinclair, J. B. (1988). Soybean germplasm evaluation for resistance to Colletotricum truncatum. Plant Dis., 72: 56-59.

McCutheon, A.R., Ellis, R.E.W., Hancock, R.E.W. and Towers, G.H.N. (1994). Antifungal screening of medicinal plant of British Columian native peoples. J. Ethnopharmacol., 44 (3): 157-169.

Maxwell, D.P., and Batman, D. F. (1976). Changes in the activity of some oxidases in extracts of Rhizoctonia infected bean hypocotyls in relation to lesion maturation. Phytopathology, 57: 132-136.

McGrath, M. T. (2004). Protectant fungicides for managing powdery mildew in cucurbits: How do they stack up ?. Vegetable MD On line. Dept. of Plant Pathology, Ithaca, Ny 14833. Magaret Tuttle McGrath, Associate Professor. Dept. of Plant Pathology, Long Island Horticulture Research and Extension Center / Cornell University 3059 sound Avenue, River heals Ny1190, May Zaeir.

Mosa, A.A. (2002). Induced resistance in rice against blast disease using a biotic and biotic agents. Ann. Agric. Sci., Ain Shams Univ., Cairo, 47(3): 993-1008.

Navarro, V., Villarreal, M.L., Rojas, G. and Lozoya, X. (1996). Antimicrobial evaluation of some plants used in Mexican traditional medicine for the treatment of infectious diseases. J. Ethnopharmacol., 53 (3): 143-147.

Nawar, H.F. and Kuti, J.D. (2003). Wyerone acid phytoalexin synthesis and peroxidase activity as markers for resistance of broad beans to chocolate spot disease. J. Phytopathol., 151: 564-570.

Pena, M. and Kuc, J.A. (1992). Peroxidase-generated hydrogen peroxidase as a source of antifungal activity in vitro and on tobacco leaf disks. Phytopathology, 82: 696-699.

Reguchender, T., Kajappan, K.and Samiappan, R. (1997). Evaluating methods of application of biocontrol agent in the control of mungbean root rot. Indian Phytopathology, 50 (2): 229-234.

Ride, J.P. (1983). Cell walls and other structural barriers in defense. In: Biochemical Plant Pathology. Calloz, J.A.(ed.), John Wiley and Sons, New York, USA.

Saber, M.M., Abdou, Y. A., El-Gantiry, S. M. and Ahmed, S. S. (2003). Biocontrol of anthracnose disease of soybean caused by Colletotricum dematium. Egypt. J. Phytopathol., 31(1-2): 17-29

Sankar, P. and Jeyarajan, R. (1996). Biological control of Sesamum root rot by seed treatment with Trichoderma spp. and Bacillus subtilis. Indian Journal of Mycology and Plant Pathology, 26(2): 217-220.

Satish, S., Mohana, D.C., Ranhavendra, M.P. and Raveesha, K.A. (2007). Antifungal activity of some plant extracts against important seed borne pathogens of Aspergillus sp. Journal of Agricultural Technology, 3(1): 109-119. 
Singh, U. P., Prithiviraj, B., Singh, K. P. and Sarma, B. K. (2000). Control of powdery mildew (Erysiphe pisi) of pea (Pisum sativum) by combined application of plant growth promoting. Zeitschrit-planzenkrankheiten und planzenschutz, 107:59-66.

Snedecor, G. W. and Cochran, W. G. (1982). Statical Methods. 6 ed., The Iowa State Univ. Press, Ames, Iowa USA.

Tarred, A.M., El-Hyatemy, Y.Y. and Omar, S.A.(1993). Wyerone derivatives and activities of peroxidase and polyphenol oxidase in faba bean leaves as induced by chocolate spot disease. Plant. Sci., 89: 161-165.

Thomas, C. E (1986). Downy and powdery mildew resistant muskmelon breeding line MR-1. Hort. Science, 21(2): 329 .

Umesha, S., Dharmesh, S. M., Shetty, S. A., Krishnappa, M. and Shetty, H. S. (1999). Biocontrol of downy mildew disease of pearl millet using Pseudomonas fluorescens. Crop Protection, 17(5): 387-392.

Vance, C.P., Kirk, T.K. and Sherwood, R.T. (1980). Lignification as a mechanism of disease resistance. Annu. Rev. Phytopathol., 18: 259-288.

Table 1. Effect of culture filtrates of Trichoderma harzianum, Epicoccum sp., Streptomyces endus, one isolate of actenomycetes (25 and 50\% v/v sterilized water) and plant extracts of Salvadora persica and Lawsona inermis on disease incidence and severity of powdery mildew of zinnia plants

\begin{tabular}{llllll}
\hline \multirow{2}{*}{$\begin{array}{l}\text { Treatments } \\
\text { rats }\end{array}$} & $\begin{array}{l}\text { Application } \\
\text { rats }\end{array}$ & \multicolumn{2}{l}{$\begin{array}{l}\text { Average no. of spots/leaf } \\
\text { (Diseaseincidence) }\end{array}$} & $\begin{array}{l}\text { Percent of surface infected } \\
\text { area (Disease severity) }\end{array}$ \\
\cline { 2 - 6 } & & 2006 & 2007 & 2006 & 2007 \\
\hline $\begin{array}{l}\text { Trichoderma } \\
\text { harzianum }\end{array}$ & $25 \%$ & $3.61 \mathrm{i}$ & $4.02 \mathrm{i}$ & $12.6 \mathrm{~g}$ & $13.2 \mathrm{~g}$ \\
Streptomyces & $25 \%$ & $2.08 \mathrm{k}$ & $3.00 \mathrm{k}$ & $7.7 \mathrm{k}$ & $8.1 \mathrm{j}$ \\
endus & $50 \%$ & $6.10 \mathrm{~b}$ & $7.06 \mathrm{~b}$ & $16.5 \mathrm{c}$ & $17.6 \mathrm{c}$ \\
& $5.31 \mathrm{~d}$ & $5.20 \mathrm{f}$ & $14.8 \mathrm{~d}$ & $13.9 \mathrm{f}$ \\
Epicoccum sp & $25 \%$ & $4.20 \mathrm{~h}$ & $3.11 \mathrm{j}$ & $9.6 \mathrm{~h}$ & $8.7 \mathrm{i}$ \\
& $50 \%$ & 2.031 & 2.041 & 6.41 & 6.81 \\
Isolate & $25 \%$ & $5.12 \mathrm{e}$ & $6.35 \mathrm{c}$ & $19.3 \mathrm{~b}$ & $20.1 \mathrm{~b}$ \\
actinomycete & $50 \%$ & $3.21 \mathrm{j}$ & $5.02 \mathrm{~g}$ & $14.5 \mathrm{e}$ & $16.2 \mathrm{~d}$ \\
Miswak extract & - & $5.54 \mathrm{c}$ & $6.25 \mathrm{~d}$ & $8.9 \mathrm{i}$ & $10.2 \mathrm{~h}$ \\
Henna extract & - & $4.49 \mathrm{~g}$ & $4.26 \mathrm{~h}$ & $7.9 \mathrm{j}$ & $7.2 \mathrm{k}$ \\
Kemah zein $75 \%$ & $2 \mathrm{~g} / \mathrm{l}$ & $5.03 \mathrm{f}$ & $6.11 \mathrm{e}$ & $12.9 \mathrm{f}$ & $14.2 \mathrm{e}$ \\
$\begin{array}{l}\text { Distilled water } \\
\text { (control) }\end{array}$ & - & $30.78 \mathrm{a}$ & $35.69 \mathrm{a}$ & $87.2 \mathrm{a}$ & $91.5 \mathrm{a}$ \\
\hline
\end{tabular}

Means within a column having the same letters are not significantly different according to Duncan,s Multiple Range Test. 
Table 2. Activity of peroxidase in leaves of Zinnia plants after $24 \mathrm{hrs}$ from treating with culture filtrates of $T$. harzianum, Epicoccum sp., Str. Endus, one isolate of actenomycetes and plant extracts of S. persica and L. inermis

\begin{tabular}{|c|c|c|c|c|c|}
\hline \multirow[t]{2}{*}{ Treatments } & \multirow{2}{*}{$\begin{array}{l}\text { Application } \\
\text { rats }\end{array}$} & \multicolumn{4}{|c|}{ Peroxidase activity/minute } \\
\hline & & 1 & 2 & 3 & 4 \\
\hline \multirow{2}{*}{$\begin{array}{l}\text { Trichoderma } \\
\text { harzianum }\end{array}$} & $25 \%$ & $0.501 \mathrm{~g}$ & $0.506 \mathrm{f}$ & $0.511 \mathrm{~g}$ & $0.517 \mathrm{~g}$ \\
\hline & $50 \%$ & 0.0071 & $0.020 \mathrm{j}$ & $0.037 \mathrm{k}$ & $0.059 \mathrm{k}$ \\
\hline \multirow{2}{*}{$\begin{array}{l}\text { Streptomyces } \\
\text { endus }\end{array}$} & $25 \%$ & $0.811 \mathrm{~d}$ & $0.816 \mathrm{~b}$ & $0.827 \mathrm{~b}$ & $0.835 b$ \\
\hline & $50 \%$ & $0.625 b$ & $0.635 \mathrm{e}$ & $0.642 \mathrm{f}$ & $0.644 f$ \\
\hline \multirow{2}{*}{ Epicoccum sp } & $25 \%$ & $0.921 \mathrm{c}$ & $0.928 \mathrm{a}$ & $0.933 \mathrm{a}$ & $0.941 \mathrm{a}$ \\
\hline & $50 \%$ & $0.747 \mathrm{a}$ & $0.756 \mathrm{c}$ & $0.768 \mathrm{c}$ & $0.777 \mathrm{c}$ \\
\hline \multirow{2}{*}{$\begin{array}{l}\text { Isolate of } \\
\text { actinomycete }\end{array}$} & $25 \%$ & $0.655 f$ & $0.659 \mathrm{~d}$ & $0.664 \mathrm{e}$ & $0.670 \mathrm{e}$ \\
\hline & $50 \%$ & $0.345 \mathrm{j}$ & $0.449 \mathrm{~g}$ & $0.466 \mathrm{~h}$ & $0.476 \mathrm{~h}$ \\
\hline Miswak extract & - & $0.434 \mathrm{~h}$ & $0.460 \mathrm{~g}$ & $0.469 \mathrm{~h}$ & $0.483 \mathrm{~h}$ \\
\hline Henna extract & - & $0.734 \mathrm{e}$ & $0.741 \mathrm{c}$ & $0.746 \mathrm{~d}$ & $0.758 \mathrm{~d}$ \\
\hline Kemah zein $75 \%$ & $2 \mathrm{~g} / 1$ & $0.112 \mathrm{k}$ & $0.115 \mathrm{i}$ & $0.121 \mathrm{j}$ & $0.125 \mathrm{j}$ \\
\hline $\begin{array}{l}\text { Distilled water } \\
\text { (control) }\end{array}$ & - & $0.403 \mathrm{i}$ & $0.405 \mathrm{~h}$ & $0.409 \mathrm{i}$ & $0.413 \mathrm{i}$ \\
\hline
\end{tabular}

Means within a column having the same letters are not significantly different according to Duncan,s Multiple Range Test.

Table 3. Activity of polyphenol oxidase in leaves of Zinnia plants after $24 \mathrm{hrs}$ from treating with culture filtrates of T. harzianum, Epicoccum sp., Str. Endus, one isolate of actenomycetes and plant extracts of S. persica and L. inermis

\begin{tabular}{llllll}
\hline \multirow{2}{*}{ Treatments } & $\begin{array}{l}\text { Application } \\
\text { rats }\end{array}$ & \multicolumn{4}{c}{ Peroxidase activity/minute } \\
\cline { 3 - 6 } & & 1 & 2 & 3 & 4 \\
\hline Trichoderma & $25 \%$ & $0.080 \mathrm{de}$ & $0.084 \mathrm{~d}$ & $0.085 \mathrm{e}$ & $0.088 \mathrm{ef}$ \\
harzianum & $50 \%$ & $0.115 \mathrm{~b}$ & $0.130 \mathrm{~b}$ & $0.0134 \mathrm{~b}$ & $0.140 \mathrm{~b}$ \\
Streptomyces & $25 \%$ & $0.078 \mathrm{de}$ & $0.085 \mathrm{~d}$ & $0.089 \mathrm{de}$ & $0.094 \mathrm{def}$ \\
endus & $50 \%$ & $0.113 \mathrm{~b}$ & $0.126 \mathrm{~b}$ & $0.130 \mathrm{~b}$ & $0.133 \mathrm{~g}$ \\
Epicoccum $\mathrm{sp}$ & $25 \%$ & $0.102 \mathrm{bc}$ & $0.105 \mathrm{c}$ & $0.111 \mathrm{c}$ & $0.115 \mathrm{c}$ \\
Isolate & $50 \%$ & $0.186 \mathrm{a}$ & $0.220 \mathrm{a}$ & $0.224 \mathrm{a}$ & $0.227 \mathrm{a}$ \\
actinomycete & $25 \%$ & $0.069 \mathrm{e}$ & $0.075 \mathrm{~d}$ & $0.079 \mathrm{e}$ & $0.084 \mathrm{f}$ \\
Miswak extract & $50 \%$ & $0.118 \mathrm{~b}$ & $0.119 \mathrm{bc}$ & $0.121 \mathrm{bc}$ & $0.122 \mathrm{c}$ \\
Henna extract & - & $0.084 \mathrm{de}$ & $0.102 \mathrm{c}$ & $0.103 \mathrm{~cd}$ & $0.105 \mathrm{cde}$ \\
Kemah zein $75 \%$ & $2 \mathrm{~g} / 1$ & $0.094 \mathrm{~cd}$ & $0.104 \mathrm{c}$ & $0.105 \mathrm{~cd}$ & $0.107 \mathrm{~cd}$ \\
$\begin{array}{l}\text { Distilled water } \\
\text { (control) }\end{array}$ & - & $0.082 \mathrm{de}$ & $0.113 \mathrm{bc}$ & $0.117 \mathrm{bc}$ & $0.119 \mathrm{c}$ \\
\hline
\end{tabular}

Means within a column having the same letters are not significantly different according to Duncan,s Multiple Range Test. 

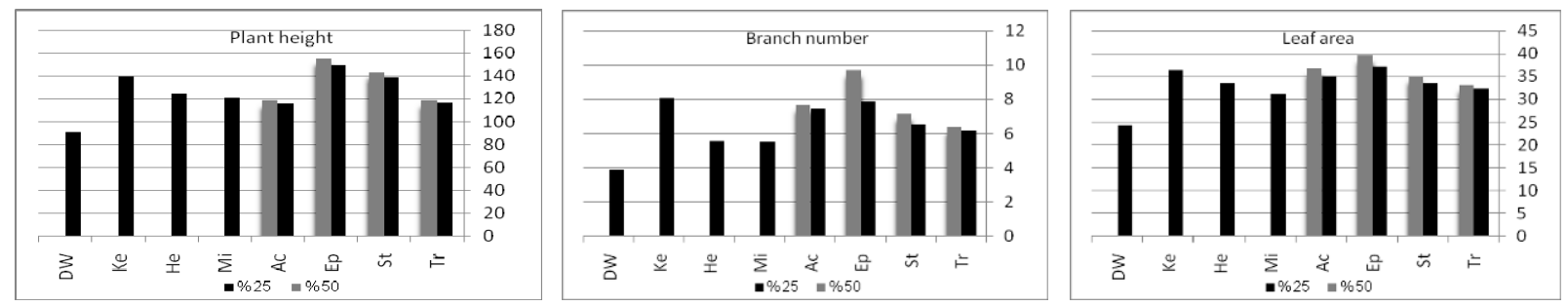

Tr: Trichoderma harzianum, St: Streptomyces endus, Ep: Epicoccum sp, Ac: isolate of actenomycetes, Mi:Miswak (Salvadora persica),He: Henna (Lawsona inermis), Ke: Kemah zein 75\% and DW: Distilled water (control).

Figure 1. Effect of culture filtrates of Trichoderma harzianum, Epicoccum sp., Streptomyces endus, one isolate of actenomycetes ( 25 and $50 \% \mathrm{v} / \mathrm{v}$ sterilized water), plant extracts of Salvadora persica and Lawsona inermis and Kemah zein $75 \%$ on plant height $(\mathrm{cm})$, Branch number/ plant and leaf area $\left(\mathrm{cm}^{2}\right)$ of Zinnia elegans, L.

(average of both seasons)
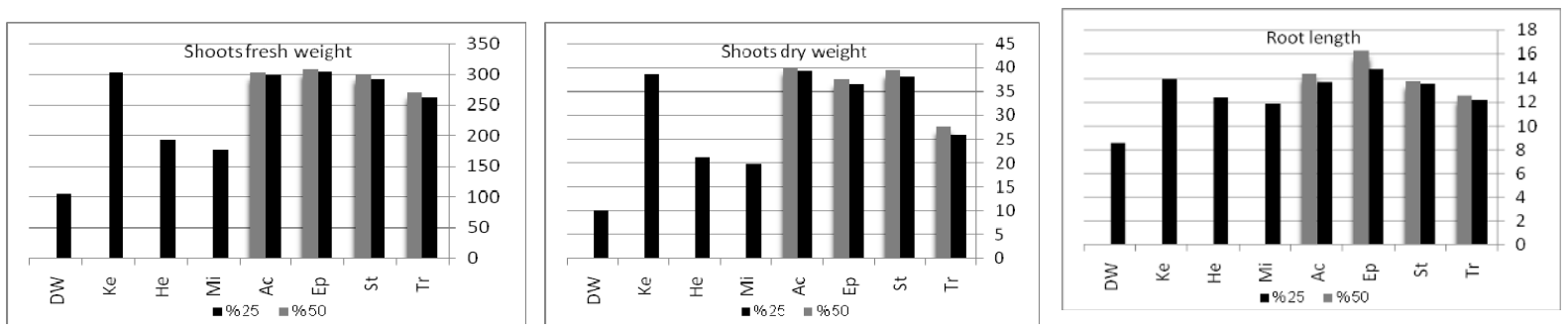

Tr: Trichoderma harzianum, St: Streptomyces endus, Ep: Epicoccum sp, Ac: isolate of actenomycetes, Mi:Miswak (Salvadora persica),He: Henna (Lawsona inermis), Ke: Kemah zein 75\% and DW: Distilled water (control).

Figure 2. Effect of culture filtrates of Trichoderma harzianum, Epicoccum sp., Streptomyces endus, one isolate of actenomycetes ( 25 and $50 \% \mathrm{v} / \mathrm{v}$ sterilized water), plant extracts of Salvadora persica and Lawsona inermis and Kemah zein $75 \%$ on shoots fresh and dry weights $(\mathrm{g}) / \mathrm{plant}$ and root length $(\mathrm{cm})$ of Zinnia elegans, $\mathrm{L}$.

(average of both seasons)
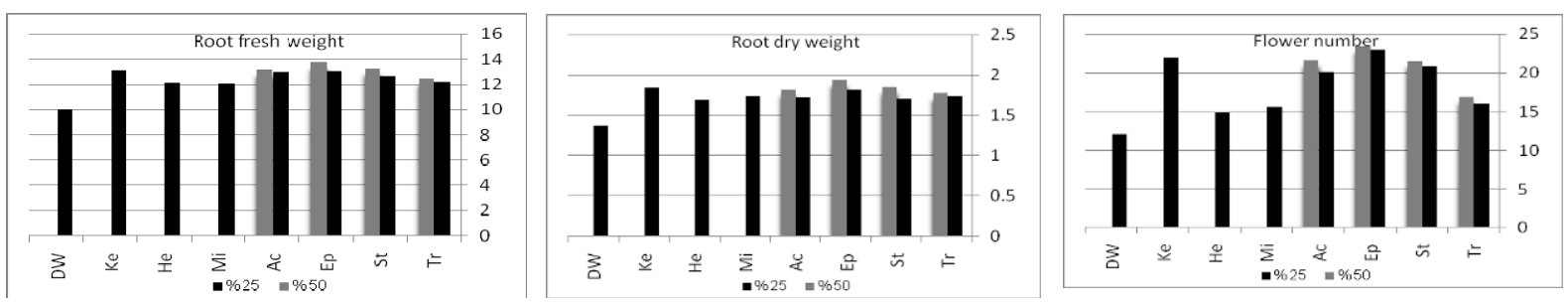

Tr: Trichoderma harzianum, St: Streptomyces endus, Ep: Epicoccum sp, Ac: isolate of actenomycetes, Mi:Miswak (Salvadora persica),He: Henna (Lawsona inermis), Ke: Kemah zein $75 \%$ and DW: Distilled water (control).

Figure 3. Effect of culture filtrates of Trichoderma harzianum, Epicoccum sp., Streptomyces endus, one isolate of actenomycetes ( 25 and $50 \%$ v/v sterilized water), plant extracts of Salvadora persica and Lawsona inermis and Kemah zein $75 \%$ on roots fresh and dry weights (g)/ plant and flowers number of Zinnia elegans, $\mathrm{L}$.

(average of both seasons) 

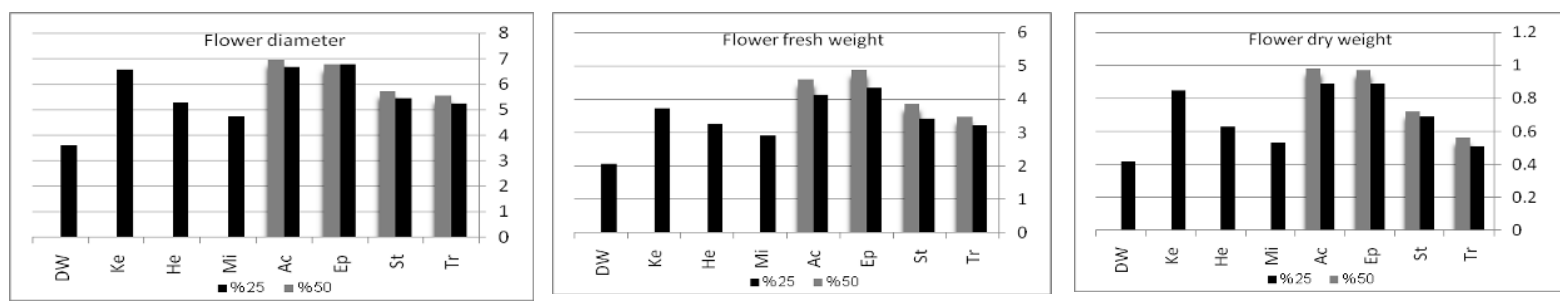

Tr: Trichoderma harzianum, St: Streptomyces endus, Ep: Epicoccum sp, Ac: isolate of actenomycetes, Mi:Miswak (Salvadora persica),He: Henna (Lawsona inermis), Ke: Kemah zein 75\% and DW: Distilled water (control).

Figure 4. Effect of culture filtrates of Trichoderma harzianum, Epicoccum sp., Streptomyces endus, one isolate of actenomycetes ( 25 and $50 \% \mathrm{v} / \mathrm{v}$ sterilized water), plant extracts of Salvadora persica and Lawsona inermis and Kemah zein $75 \%$ on flower diameter $(\mathrm{cm})$ and flower fresh and dry weights $(\mathrm{g})$ of Zinnia elegans, $\mathrm{L}$.

(average of both seasons)

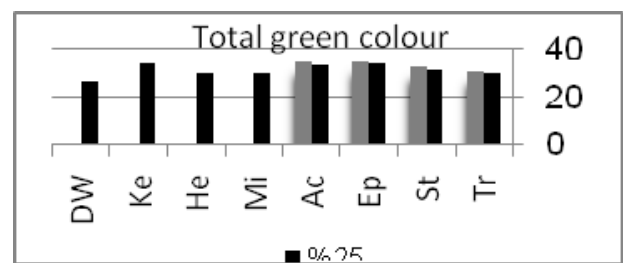

Tr: Trichoderma harzianum, St: Streptomyces endus, Ep: Epicoccum sp, Ac: isolate of actenomycetes, Mi:Miswak (Salvadora persica),He: Henna (Lawsona inermis), Ke: Kemah zein 75\% and DW: Distilled water (control).

Figure 4. Effect of culture filtrates of Trichoderma harzianum, Epicoccum sp., Streptomyces endus, one isolate of actenomycetes ( 25 and $50 \% \mathrm{v} / \mathrm{v}$ sterilized water), plant extracts of Salvadora persica and Lawsona inermis and Kemah zein $75 \%$ on total green colour (SAPD) of Zinnia elegans, L. (average of both seasons). 